\title{
Effect of silicate on arsenic fractionation in soils and its accumulation in rice plants
}

by Wu, C., Zou, Q., Xue, S., Pan, W., Hartley, W. Huang, L. and Mo, J.

Copyright, Publisher and Additional Information: This is the author accepted manuscript. The final published version (version of record) is available online via Elsevier Please refer to any applicable terms of use of the publisher.

DOI: http://dx.doi.org/10.1016/j.chemosphere.2016.09.061

Harper Adams

University 
Effect of silicate on arsenic fractionation in soils and its accumulation in rice

\section{plants}

Chuan WU ${ }^{1}$, Qi ZOU ${ }^{1}$, Sheng-Guo XUE ${ }^{1, *}$, Wei-Song PAN ${ }^{2, *}$, Liu HUANG ${ }^{1}$, William HARTLEY ${ }^{3}, \mathrm{Xu}_{\mathrm{Yue}^{2}}$, Jing-Yu MO ${ }^{1}$

1 School of Metallurgy and Environment, Central South University, Changsha 410083, China.E-mail: wuchuan@csu.edu.cn

2 College of Bioscience and Biotechnology, Hunan Agricultural University, Changsha 410128, China

3 Crop and Environment Sciences Department, Harper Adams University, Newport, Shropshire, TF10 8NB, United Kingdom

${ }^{*}$ Corresponding authors:

Tel: +86-13787148441, E-mail address: sgxue@csu.edu.cn (Shengguo Xue);

Tel: +86-15974218619, E-mail address: panweisong@hunau.edu.cn (Weisong Pan). 


\section{ABSTRACT}

Four rice genotypes, two hybrid and two indica, were selected to investigate the effects of silicate $(\mathrm{Si})$ application on arsenic (As) accumulation and speciation in rice and As fractionation in soil. There were significant differences in root, straw and grain biomass between genotypes $(\mathrm{p}<0.05)$, and $\mathrm{Si}$ application significantly increased root $(\mathrm{p}<0.05)$ and grain biomass $(\mathrm{p}<0.001)$. Silicate addition reduced the proportion of As associated with well-crystallized hydrous oxides of $\mathrm{Fe}$ and $\mathrm{Al}$ and residual phases, whilst increasing the proportions of specifically-sorbed As and As associated with amorphous and poorly-crystalline Fe and Al hydrous oxides. Furthermore, the results indicated that the fraction proportions of non-specifically sorbed, specifically-sorbed, and associated with amorphous and poorly-crystalline hydrous oxides of $\mathrm{Fe}$ and $\mathrm{Al}$ in rhizosphere soils, were greater than non-rhizosphere soils. Silicate application had a significant effect decreasing total As concentrations in root $(\mathrm{p}<0.005)$, straw $(\mathrm{p}<0.05)$ and husk $(\mathrm{p}<0.001)$ of rice plants. The effect of $\mathrm{Si}$ on reducing As accumulation in rice leaves was revealed by SXRF. Indica genotypes transported and accumulated less As than hybrid genotypes. Both percentage and concentration of iAs were lower in indica genotype XFY-9 than in hybrid genotype XWX-12. Silicate reduced iAs and DMA by $21 \%$ and $58 \%$ respectively in polished grain. DMA may have a greater translocation capacity from straw to polished grain than inorganic As. The study provides the potential for understanding As uptake mechanisms in rice and mitigating the health risks posed by As contamination in paddy fields.

Key words: Arsenic, Arsenic fractionation, Radial oxygen loss, Rice; Silicate 


\section{Introduction}

Chronic and acute arsenic (As) exposure from either drinking water or the food chain has resulted in adverse health impacts such as cancers, neurological and cardiovascular diseases (Stone et al., 2008; Guo et al., 2009; Martinez et al., 2011). Irrigation of paddy fields with As-rich groundwater and mining activities have caused serious contamination of paddy soils (Huang et al., 2006; Wang et al., 2015; Xue et al., 2016). Liao et al (2005) reported that As concentrations in rice grain grown in As-contaminated soils reached $7.5 \mathrm{mg} / \mathrm{kg}$. Generally, rice is cultivated in flooded paddy soils (Meharg et al., 2012; Pan et al., 2014). Under anaerobic conditions, the mobilization and bioavailability of As is greatly elevated, as large concentrations of As are released into pore-waters due to the reductive dissolution of Fe (hydr)oxides regulated by iron-reducing bacteria, and arsenate $(\mathrm{As}(\mathrm{V}))$ reduction to arsenite (As(III)), which is less sorbed (Roberts et al., 2011; Stroud et al., 2011; Peng et al., 2016). In addition, As(III) uptake and accumulation is more efficient in rice compared to other crops due to As(III) translocation occurring through a strong silicon uptake pathway (Su et al., 2010; Zhao et al., 2013; Pan et al., 2014), thereby resulting in greater As concentrations in rice grain (Zhu et al., 2008a,b). Studies have also shown that rice consumption is a major source of inorganic As (iAs) in the human diet (Meharg et al., 2009; Jia et al., 2012; Su et al., 2010).

Owing to the differences in toxicity and mobility of As species, total As concentrations are insufficient to indicate As bioavailability and toxicity in soils (Huang et al., 2015). Arsenic mobility, bioavailability, and toxicity largely depends on the chemical forms and types of binding (Novoa et al., 2007; Yang et al., 2016). In order to understand the bioavailability and toxicity of As to rice plants, As fractionation in soils must be understood (Li et al., 2007); this can be accomplished by 
using different extraction reagents, such as with sequential extraction procedures, to determine the chemical forms of As in soils (Wu et al., 2015). These procedures can also be used to predict changes in As mobility from various solid phases following amendment additions such as silicon (Si) (Wenzel et al., 2001).

Numerous studies have shown that silicate ( $\mathrm{Si}$ ) application not only increases rice yield, but also suppresses uptake and accumulation of As in rice grains, though $\mathrm{Si}$ was not considered as an essential element of rice ( $\mathrm{Li}$ et al., 2009a; Seyfferth and Fendorf, 2012; Fleck et al., 2013). In flooded soils, rice is inherently efficient at taking up and transferring $\mathrm{As}(\mathrm{III})$ (Su et al., 2010) due to the translocation of As(III) into rice via silicon transport systems (transporters Lis1 and Lsi 2) as a silicon acid analogue (Ma et al., 2006,2008; Chen et al., 2012). Transporter Lis 1 acts as a major uptake channel for As(III) in rice plants and Lsi 2 plays an essential role in mediating As(III) translocation to shoots and subsequent accumulation in the grains (Ma et al., 2006, 2008). Consequently competition for uptake and translocation between Si and As(III) occurs, and hydroponic experiments have demonstrated that addition of $\mathrm{Si}$ reduced As uptake and accumulation in rice (Guo et al., 2005,2007; Tripathi et al., 2013). Fleck et al (2013) reported that Si application reduced As concentrations by $22 \%$ in brown and polished rice grains by suppressing As(III) transport. Li et al (2009a) revealed that $\mathrm{Si}$ addition reduced iAs concentrations by $59 \%$ and increased DMA concentrations by $39 \%$ in rice grains. However, due to similar physicochemical properties, Si may also compete against As(III) for retention sites on soil minerals. It was found that silicate reduced arsenite adsorption rates and competed for adsorption sites, thus increasing As concentrations in soil solutions (Luxton et al., 2008; Lee et al., 2014).

The present study aimed to investigate the effect of $\mathrm{Si}$ on As mobility and 
bioavailability to rice with different radial oxygen loss (ROL) rates in rhizosphere and non-rhizosphere soils and to determine the effect of Si on As fractionation in soil, As uptake, translocation and speciation in rice plants.

\section{Materials and methods}

\subsection{Materials}

Pot experiments were conducted with four rice genotypes, comprising of hybrid genotypes Xiangfengyou 9 ('XFY-9') and T-you207 ('TY-207') and indica subspecies Xiangwanxian 17 ('XWX-17') and Xiangwanxian 12 ('XWX-12') which were obtained from Hunan Agricultural University. The four rice genotypes ROL values are as follows, $9.55,15.41,19.76$ and $27.00 \mathrm{umol} \mathrm{O}_{2} \mathrm{~g}^{-1}$ root dry weight $\mathrm{h}^{-1}$ respectively (Wu et al., 2015). Rice seeds were sterilized $\left(30 \% \mathrm{H}_{2} \mathrm{O}_{2}\right)$ for $15 \mathrm{~min}$, and then thoroughly washed with deionized water. They were then germinated in petri dishes containing moist filter paper for three days. Subsequently the seedlings were cultivated in Kimura B nutrient solution for two weeks.

The soils used in this investigation were obtained from a paddy field $(1-20 \mathrm{~cm}$ depth) located at the Central South University, China. The soils had a sandy texture, a $\mathrm{pH}$ of 6.6 and contained $9.4 \mathrm{mg} / \mathrm{kg}$ pseudo-total As. After being air-dried at room temperature, the soils were ground and sieved $(<2 \mathrm{~mm})$. Basal fertilizers were added to soils and mixed thoroughly $\left(\mathrm{P}\right.$ as $\mathrm{CaH}_{2} \mathrm{PO}_{4} \cdot \mathrm{H}_{2} \mathrm{O}$ at $0.15 \mathrm{~g} / \mathrm{kg} \mathrm{P}_{2} \mathrm{O}_{5}, \mathrm{~K}$ as $\mathrm{KCl}$ at 0.2 $\mathrm{g} / \mathrm{kg} \mathrm{K}_{2} \mathrm{O}$, and $\mathrm{N}$ as $\mathrm{CO}\left(\mathrm{NH}_{2}\right)_{2}$ at $0.2 \mathrm{~g} / \mathrm{kg} \mathrm{N}$ ) (Wu et al., 2011). 


\subsection{Pot trail under waterlogged conditions}

Soils were supplied with arsenate solution $\left(\mathrm{Na}_{2} \mathrm{HAsO}_{4} \cdot 12 \mathrm{H}_{2} \mathrm{O}\right)$ at $60 \mathrm{mg} \mathrm{As} / \mathrm{kg}$. Silicon was added as a silica gel which provided a sparingly soluble source of Si for rice growth (Seyfferth and Fendorf, 2012). Treatments were conducted as follows:

Control: no As or $\mathrm{Si}$

Treatment A: $60 \mathrm{mg} / \mathrm{kg}$ As only, no Si (Si0)

Treatment B: $60 \mathrm{mg} / \mathrm{kg}$ As and 10mg/kg Si (Si10)

Treatment C: $60 \mathrm{mg} / \mathrm{kg}$ As and 20mg/kg Si (Si20)

Treatment D: $60 \mathrm{mg} / \mathrm{kg}$ As and 40mg/kg Si (Si40).

Soils were mixed and allowed to equilibrate for two weeks, and the seedlings were subsequently transplanted into polyethylene pots $(20 \mathrm{~cm}$ diameter, $20 \mathrm{~cm}$ high) filled with $3.5 \mathrm{~kg}$ of the treated soils. All treatments were carried out in triplicate.

Following planting, soils were saturated with water and the water level was maintained $2-3 \mathrm{~cm}$ above the soil surface until harvest. Pot experiments were performed in the greenhouse with controlled temperature $\left(20 / 25{ }^{\circ} \mathrm{C}\right.$, night/day) and relative humidity (70\%). Natural sunlight was supplemented with sodium light (1200 Lux), providing a light period of $12 \mathrm{~h}$ per day. After maturity the rice plants were harvested and subsequently separated into polished grain, husks, straw and roots. The straw harvested from below the water level was discarded due to contamination by the irrigation water. Plant tissues were washed with tap water and then with deionized water. From the plant tissues subsamples were collected and freeze-dried at $-20{ }^{\circ} \mathrm{C}$ in order to preserve the As species prior to determination and the remaining samples were oven-dried at $70^{\circ} \mathrm{C}$ for total analysis. Biomass (dry weight) was also determined for root, straw and grain. 


\subsection{Sequential extraction of As}

After harvest, rhizosphere and non-rhizosphere soils were collected to determine As fractionation using the sequential extraction procedure described by Wenzel et al (2011). Soil samples $(1.0 \mathrm{~g})$ were weighted into $50 \mathrm{ml}$ centrifuge tubes and $25 \mathrm{ml}$ of each extracting reagent was added sequentially. The sequential extraction processes involved five stages as follows:

1) $0.05 \mathrm{~mol} / \mathrm{L}\left(\mathrm{NH}_{4}\right)_{2} \mathrm{SO}_{4}$ at $20{ }^{\circ} \mathrm{C}$ for $4 \mathrm{~h}$;

2) $0.05 \mathrm{~mol} / \mathrm{L} \mathrm{NH} \mathrm{H}_{2} \mathrm{PO}_{4}$ at $20{ }^{\circ} \mathrm{C}$ for $16 \mathrm{~h}$;

3) $0.2 \mathrm{~mol} / \mathrm{L} \mathrm{NH}_{4}+-$ oxalate buffer in the dark at $\mathrm{pH} 3.25$ and $20{ }^{\circ} \mathrm{C}$ for $4 \mathrm{~h}$;

4) $0.2 \mathrm{~mol} / \mathrm{L} \mathrm{NH}_{4}{ }^{+}$-oxalate buffer + ascorbic acid at $\mathrm{pH} 3.25$ and $96{ }^{\circ} \mathrm{C}$ for $0.5 \mathrm{~h}$;

5) $\mathrm{HNO}_{3} / \mathrm{H}_{2} \mathrm{O}_{2}$ with microwave digestion.

Following each extraction stage, solutions were centrifuged for $15 \mathrm{~min}$ at $1700 \mathrm{~g}$ and the supernatant was filtered through $0.45 \mu \mathrm{m}$ filters. The soils were then washed with deionized water $(25 \mathrm{ml})$ and centrifuged prior to the next extraction stage, washings were discarded. Arsenic concentrations in the filtered supernatants were determined as described in section 2.4. Samples were analyzed in duplicate. The As fractions extracted were associated with the following adsorption sites: 1) non-specifically sorbed (F1); 2) specifically-sorbed (F2); 3) associated with amorphous and poorly-crystalline hydrous oxides of $\mathrm{Fe}$ and $\mathrm{Al}$ (F3); 4) associated with well-crystallized hydrous oxides of $\mathrm{Fe}$ and $\mathrm{Al}(\mathrm{F} 4) ; 5)$ residual phase (F5).

\subsection{Plant analysis for total As}

All plant samples for total As analysis were ground to fine powders using a stainless steel mechanical mill. Samples $(0.5 \mathrm{~g})$ were weighed and digested overnight at room temperature with $5 \mathrm{~mL} \mathrm{HNO}_{3}(65 \%)$. The digestion was performed on an 
electric hot plate at $120^{\circ} \mathrm{C}$ until the solution became clear. After digestion, the solution was filtered $(0.45 \mu \mathrm{m})$ and diluted to $20 \mathrm{ml}$ with deionized water in volumetric tubes. The total As concentrations were determined by HG-AFS (AFS-8230, Beijing Jitian Instruments Co., China) (Wu et al., 2016). A certified reference material, bush branches and leaves, GBW07603, was used to confirm recovery of the digestion methods.

At harvest, SXRF microprobe experiments were performed to determine the effects of $\mathrm{Si}$ application on As accumulation in rice leaves, performed at beamline LU15 at the Shanghai Institute of Applied Physics, Chinese Academy of Science. Incident X-rays of $8.1 \mathrm{keV}$ were used to excite elements from leaf samples, which had been placed in liquid nitrogen immediately after cutting from the live plant (Zheng et al., 2011; Zhu et al., 2016).

\subsection{As speciation in rice plants}

Plant samples for As speciation were ground under liquid $\mathrm{N}_{2}$ to avoid changes to As species (Zhu et al., 2008b). Samples (0.1g) were extracted with $20 \mathrm{ml} 0.28 \mathrm{M}$ nitric acid placed on heating blocks at $95{ }^{\circ} \mathrm{C}$ for $90 \mathrm{~min}$ in centrifuge tubes $(50 \mathrm{ml})$. Following centrifugation at 5000r/min (10 min), samples were filtered $(0.22 \mu \mathrm{m})$ and the extracts were determined by HPLC-HG-AFS (HPLC, Shimadzu LC-15C Suzhou Instruments Co., China; HG-AFS, AFS-8230, Beijing Jitian Instruments Co., China) (Zhu et al., 2008b; Shi et al., 2013).

\subsection{Data analysis}

Analysis of variance were determined by the statistical package SPSS 19.0 and all figures were created using the scientific graphing and data analysis software Origin 
8.0 (OriginLab Corporation, USA).

\section{Results}

\subsection{The effect of Si on plant growth}

Biomass of root, straw and grain from the different treatments are presented in Fig. 1. There were significant differences in root $(\mathrm{p}<0.05)$, straw $(\mathrm{p}<0.001)$ and grain biomass $(\mathrm{p}<0.001)$ between genotypes. Silicon application significantly increased root $(\mathrm{p}<0.05)$ and grain biomass $(\mathrm{p}<0.001)$. Root biomass of plants varied from $9.25 \mathrm{~g} / \mathrm{pot}$ to $15.8 \mathrm{~g} /$ pot in control treatments. Compared to $\mathrm{Si} 0, \mathrm{Si}$ increased root biomass of the hybrid genotypes (XFY-9 and TY-207) by $27 \%$ and $49 \%$ respectively and indica genotypes (XWX-17 and XWX-12) by $1 \%$ and $7 \%$ respectively. Greatest root biomass was observed from genotypes TY-207 and XWX-17 grown in Si20 treatment and genotypes XFY-9 and XWX-12 grown in Si40 treatment. Compared to $\mathrm{Si0}$ treatment, Si increased straw biomass of the hybrid genotypes (XFY-9 and TY-207) by $22 \%$ and $27 \%$ respectively and the indica genotypes (XWX-17 and XWX-12) by $1 \%$ and $24 \%$ respectively; greatest straw biomass was observed in genotypes XFY-9 and TY-207 grown in Si20 treatment and genotypes XWX-12 and XWX-17 in Si40 treatment. Grain biomass of plants varied from $6.4 \mathrm{~g} /$ pot to $14.8 \mathrm{~g} / \mathrm{pot}$ in control treatments. Compared to $\mathrm{Si} 0$ treatments, $\mathrm{Si}$ increased grain biomass of the hybrid genotypes (XFY-9 and TY-207) by $60 \%$ and $58 \%$ respectively and the indica genotypes (XWX-17 and XWX-12) by 52\% respectively; Greatest grain biomass was observed in genotype TY-207 grown in Si20 treatment and genotypes XFY-9, XWX-12 and XWX-17 in Si40 treatments. 


\subsection{The effect of Si on As fractionation in soils}

Figure 2 shows the relative distribution of As in rhizosphere soils with different Si treatments. Concentrations of the five fractions were ranked as: F3 $>$ F2 $>$ F4 > F5 > F1 for all treatments. There was no significant genotypic difference between As fractions. Silicon addition may have reduced the concentrations of F4 and F5 fractions, whilst increasing the As fractions associated with F2 and F3 (Fig 2). With the exception of $\mathrm{Si} 40$, the other $\mathrm{Si}$ treatments increased As concentrations in the $\mathrm{F} 1$ fraction compared to $\mathrm{Si} 0$.

Arsenic fractionation in non-rhizosphere soils is presented in Fig 2. The five fractions displayed a similar order with rhizosphere soils. Results indicated that F5 and F4 fractions in non-rhizosphere soils were much higher than rhizosphere soils in the same treatment (Fig. 2). Fractions F1, F2 and F3 in non-rhizosphere soils were also lower than rhizosphere soils. With increasing Si, the concentrations of fraction F5 decreased in all four genotypes. Silicon application increased the concentrations of the $\mathrm{F} 2$ and $\mathrm{F} 3$ fractions. In $\mathrm{Si} 0$ treatment, fraction $\mathrm{F} 3$ in non-rhizosphere soils for all genotypes with lower ROL was greater than genotypes with higher ROL, whilst the F4 fraction presented the opposite trend.

\subsection{The effect of Si on total As in rice plants}

Total As concentrations in rice plants grown in control treatments were below the detection limit. Significant genotypic differences were observed for total As of roots $(p<0.05)$, husks $(p<0.01)$ and polished grains $(p<0.001)$. Silicon application had a

significant effect by decreasing total As concentrations in roots $(\mathrm{p}<0.005)$, straw $(\mathrm{p}<0.05)$ and husks $(\mathrm{p}<0.001)$ of rice plants (Table 1). Total As concentrations in roots varied from $488 \mathrm{mg} / \mathrm{kg}$ to $946 \mathrm{mg} / \mathrm{kg}$, with the highest total As concentrations in $\mathrm{Si} 0$ 
treatment of genotype XWX-12 and the lowest in Si40 treatment of genotype TY207. Overall Si treatments reduced total As concentrations in roots by approximately $32 \%$. Genotype XWX-17 displayed the lowest total As concentrations in straw, $7.24 \mathrm{mg} / \mathrm{kg}$ in Si40 treatment, and genotype XWX-12 showed the greatest concentration, $12.8 \mathrm{mg} / \mathrm{kg}$, grown in $\mathrm{Si} 0$ treatment. Application of Si reduced total As concentrations in straw by approximately $25 \%$.

Polished grain As concentrations of indica genotypes were significantly lower than hybrid genotypes grown in the same treatments $(\mathrm{P}<0.001)$. Genotype XWX-12 $(1.63 \pm 0.08 \mathrm{mg} / \mathrm{kg})$ and XFY-9 $(2.73 \pm 0.22 \mathrm{mg} / \mathrm{kg})$ produced the lowest and greatest As concentrations in control treatments respectively. The results indicated that the indica genotypes transported and accumulated less As than the hybrid genotypes. Polished grain As concentrations varied from $0.94 \mathrm{mg} / \mathrm{kg}$ to $2.73 \mathrm{mg} / \mathrm{kg}$, and the lowest polished grain As concentration was observed in Si40 treatment of genotype XWX-12. Silicon application clearly affected the translocation capability (Figure 3). With increasing straw As concentrations, As slightly decreased in polished grain. With increasing Si concentrations, translocation of As from straw to grain increased, with As concentration in polished grains almost having no change in Si40 treatment regardless of increasing straw As (Figure 3).

\subsection{The effect of Si on As localization in rice leaves}

SXRF imaging (Fig 4a and 4b) demonstrated that the main leaf veins contained high As signals, stronger intensities and larger As signals in plants grown with no Si (Fig 3a) compared to those with Si addition (Fig 3b). SXRF imaging indicated that Si addition reduced As accumulation in leaves and reduced the translocation of As from straw to leaves. 


\subsection{The effect of Si on As speciation in rice plants}

Owing to possible conversion of arsenite to arsenate, the concentrations of inorganic As (iAs) were adopted to represent the concentrations of As(III) and As(V) (Wu et al., 2015). Inorganic As (78\%-91\%) was the predominant As species in rice straw (Table 2). The proportion of iAs in hybrid genotype XFY-9 was greater than genotype indica XWX-12 with the exception of Si20 treatment. Silicon decreased iAs concentrations in rice straw by $8 \%-60 \%$. With increasing Si, DMA concentrations in XFY-9 increased initially, but then decreased, whilst in XWX-12, DMA concentrations reduced. The main As species in rice husk were iAs (22\%-43\%) and DMA (56\%-77\%) (Table 3). MMA accounted for approximately $1 \%$ of total As. Silicon addition decreased both iAs and DMA concentrations by 55\% and $43 \%$ respectively. Table 4 presents the As species in rice grains grown in the different treatments; MMA concentration was not detected. DMA was the dominant As species representing $90.9 \%-95.4 \%$, whilst iAs contributed between $4.6 \%-9.1 \%$. The percentage and concentrations of iAs in hybrid genotype XFY-9 were both greater than indica genotype XWX-12 (Figure 5). Figure 5 indicated that DMA may have greater translocation capacity than iAs from straw to polished grain. In polished grain, Si reduced iAs and DMA by $21 \%$ and $58 \%$ respectively (Table 4 ).

\section{Discussion}

It is already well understood that $\mathrm{Si}$ application exerts beneficial effects on plant growth and yield by enhancing resistance to both biotic and abiotic stresses (Ma et al., 2006). Silicon can also alleviate the toxicity of contaminants such as As in rice (Fleck 
et al., 2013). The beneficial effects of $\mathrm{Si}$ on plant growth have been observed in previous studies by $\mathrm{Li}$ et al (2009a) and Fleck et al (2013) who reported that Si addition increased rice straw and grain yields. Results from this investigation have demonstrated that $\mathrm{Si}$ application significantly increased root $(\mathrm{p}<0.05)$ and grain biomass $(\mathrm{p}<0.001)$ (Figure 1).

Studies have also demonstrated that Si application increased As concentrations in soil solution (Bogdan et al., 2008; Seyfferth and Fendorf, 2012; Fleck et al., 2013; Liu et al., 2014; Lee et al., 2014). Liu et al (2014) and Lee et al (2014) both indicated that it may be due to Si and As competing for similar adsorption sites on soil minerals, but the definite mechanism remained elusive. Previous studies have also reported that As is primarily associated with amorphous and poorly-crystalline hydrous oxides of $\mathrm{Fe}$ and $\mathrm{Al}$ and with well-crystallized hydrous oxides of $\mathrm{Fe}$ and $\mathrm{Al}$ (Wenzel et al., 2001; Smith et al., 2008); this was observed in this study regardless of rhizosphere or non-rhizosphere soil type (Figure 2). Our results demonstrated that $\mathrm{Si}$ application increased both the non-specifically and specifically sorbed $(\mathrm{p}<0.01)$ fractions of As but reduced the amorphous and poorly-crystalline hydrous oxides of $\mathrm{Fe}$ and $\mathrm{Al}$, well-crystallized hydrous oxides of $\mathrm{Fe}$ and $\mathrm{Al}(\mathrm{P}<0.05)$ and residual fraction in rhizosphere soils (Table 1). Increases in non-specifically sorbed, specifically sorbed and amorphous and poorly crystalline hydrous oxides of $\mathrm{Fe}$ and $\mathrm{Al}$ fractions of As and reductions in well-crystallized hydrous oxides of $\mathrm{Fe}$ and $\mathrm{Al}$ and residual fractions were observed in non-rhizosphere soils. Non-specifically sorbed, specifically sorbed and amorphous and poorly crystalline hydrous oxides of $\mathrm{Fe}$ and $\mathrm{Al}$ fractions of As are considered to constitute the main proportion of bioaccessible As. The fraction associated with amorphous and poorly-crystalline hydrous oxides of $\mathrm{Fe}$ and $\mathrm{Al}$ is the key factor controlling the bioaccessibility of As (Tang et al., 2007; Smith et al., 2008), 
with well-crystallized hydrous oxides of $\mathrm{Fe}$ and $\mathrm{Al}$ and residual fractions being relatively stable and less bioavailable (Wenzel et al., 2001). Results from this investigation show that both $\mathrm{Si}$ and the rhizosphere environment have an effect on As fractionation. Indeed, Si application not only redistributed As, but it also increased its bioaccessibility and concentrations in the soil solution.

The sequential extraction results also revealed that there were differences in As fractions (non-specifically sorbed and amorphous and poorly-crystalline hydrous oxides of $\mathrm{Fe}$ and $\mathrm{Al}$ ) between rhizosphere and non-rhizosphere soils. In rhizosphere soils non-specifically sorbed and amorphous and poorly-crystalline hydrous oxides of $\mathrm{Fe}$ and $\mathrm{Al}$ fractions of As were greater than those in non-rhizosphere soils, whilst for non-rhizosphere soils As concentrations were greater in specifically-sorbed, well-crystallized hydrous oxides of Fe and Al and residual fractions (Fig 4). Studies have demonstrated that ROL has profound influences on the rhizosphere environment including contaminant mobility (Wu et al., 2011, 2016). For example, Wu et al (2015) reported that root oxygenation greatly affected As mobility in soils whilst oxygenation followed by ROL contributed to the co-precipitation of Fe and heavy metals (Comer et al., 2003), increasing As in the amorphous and poorly-crystalline hydrous oxides of $\mathrm{Fe}$ and $\mathrm{Al}$ fraction in rhizosphere soils. In addition, the residual fraction which is associated with recalcitrant materials like sulfides (FeAsS) and organic matter (Huang et al., 2015), may become oxygenated by plant roots and microbial activity thereby converting $\mathrm{Fe}^{2+}$ to $\mathrm{Fe}^{3+}$ (Mei et al., 2009). Ferric iron may accelerate the oxidation-dissolution reaction of arsenic-bearing minerals such as arsenopyrite and arsenian pyrite, which may result in formation of $\mathrm{FeAsO}_{4} \cdot 2 \mathrm{H}_{2} \mathrm{O}$ (Forest et al., 1977: 
Sanchez et al., 2003); this may increase As in amorphous and poorly-crystalline hydrous oxides of $\mathrm{Fe}$ and $\mathrm{Al}$ fraction but reduce the residual fraction. In addition, oxidation by rice roots may stimulate microbial activity in rhizosphere soils, thereby further influencing As behavior (Jia et al., 2014).

In anoxic environments such as waterlogged paddy soils, the majority of As is present as As(III) (Takahashi et al., 2004; Xu et al., 2008; Pan et al., 2014). As a silicic acid analogue, As(III) efficiently enters into rice roots by sharing the $\mathrm{Si}$ transport pathway (Ma et al., 2008). Competition for uptake and translocation between Si and As may therefore occur in rice plants (Lee et al., 2014). Our results indicated that adding $\mathrm{Si}$ reduced As concentrations in rice roots $(\mathrm{p}<0.005)$, straw $(\mathrm{p}<0.05)$, husks $(\mathrm{p}<0.001)$ and grain $($ Table 2$)$. This was in agreement with previous studies, showing that $\mathrm{Si}$ addition significantly reduced As concentrations in rice roots and shoots grown in solution cultures ((Guo et al., 2005, 2007; Tripathi et al., 2013). Fleck et al (2013) reported that Si application limited As(III) uptake and translocation into shoots and subsequent transportation into grain. Arsenic concentrations in straw, flag leaves, and husks were reduced by half while As concentrations in brown and polished rice were reduced by $22 \%$. Seyfferth and Fendorf (2012) also reported that silica gel applied to soil decreased straw and grain As concentrations in rice plants. Bogdan and Schenk (2008) discovered a negative correlation between dissolved Si concentrations in soil solution and As concentrations in rice straw and grain. Similarly, Li et al (2009a) found that $\mathrm{Si}$ addition decreased straw and grain As concentrations by $78 \%$ and $16 \%$ respectively. However the above studies revealed that $\mathrm{Si}$ application increased As concentrations in the soil solution due to competition between Si and As for soil absorption sites and the suppressing effect of Si on As accumulation was observed in rice plants (Li et al., 2009a; Seyfferth and Fendorf, 2012; Fleck et al., 
2013). This was similar to studies by Liu et al (2014) who reported that Si increased As(III) concentrations in soil solution but decreased the As(III) accumulation in rice plants. Our sequential extraction results also indicated that Si application enhanced As bioavailability and mobility in the soil solution, and this effect was much smaller than the inhibitory effect of $\mathrm{Si}$ on As uptake in rice plants. In addition, there were significant genotypic effects on As concentrations in rice roots $(\mathrm{p}<0.05)$, husks $(\mathrm{p}<0.01)$ and grains $(\mathrm{p}<0.001) \quad($ Table 2$)$. Indica genotypes, with higher ROL, accumulated lower As concentrations than hybrid genotypes with lower ROL. Rice plants with higher ROL induced extra iron plaque formation, which subsequently sequestered more As and resulted in less As accumulation in above-ground tissues (Mei et al., 2012; Wu et al., 2016).

Previous studies have indicated that there is a genotypic difference in As speciation in rice (Mei et al., 2009; Wu et al., 2011). Previous studies have shown that the predominant As species presented in rice straw is inorganic As (Zavala et al.,2008; Zheng et al., 2011), which corresponds with our results. Arsenic speciation is greatly affected by the soil environment and under waterlogged conditions As(III) has been identified as the main species presented with DMA at much lower concentrations (Takahashi et al., 2004; Xu et al., 2008; Smith et al.,2008). In addition, Abedin et al (2002) reported a greater affinity for inorganic As than organic As forms in rice, and this may explain the reason why inorganic As accounted for the majority of total As in rice straw. The results from this study have demonstrated that As speciation differed between genotypes and this may be the result of variation in root uptake or internal translocation efficiency of different As species within different genotypes (Zhao et al., 2013a; Wu et al., 2016). Additionally, differences in translocation efficiency of both iAs and DMA between the two genotypes also confirmed this 
assumption. Numerous studies have reported that DMA is the dominant As species in grain (Smith et al.,2008; Zheng et al., 2013; Syu et al., 2015). Zheng et al (2013) showed that DMA has greater mobility than inorganic As in both xylem and phloem, and DMA was inclined to accumulate in the caryopsis whilst inorganic As was mainly sequestered in vegetative tissues; Carey et al (2011) reported that DMA was easily transported into rice grain. As the predominant species in paddy soils (Pan et al., 2014), As(III) is a silicic acid analogue and is assimilated via silicic acid transporters Lsi 1 and Lsi 2 (Ma et al., 2008; Chen et al., 2012). Rice aquaporin Lsi 1 was also considered to mediate the uptake of DMA and MMA in rice plants (Li et al., 2009b), and therefore Si application may suppress $\mathrm{As}(\mathrm{III})$ uptake due to competition with $\mathrm{Si}$ for transport pathways especially Lsi 2 (Ma et al., 2008). Similarly, competition between DMA and Si for transporters may decrease DMA accumulated in grain and Li et al (2009b) reported that mutation of Lsi 1 reduced DMA uptake by approximately $50 \%$ in rice plants. In addition, $\mathrm{Si}$ application reduced the expression of transporters Lsi 1 and Lsi 2 (Ma et al., 2006, 2007). Li et al (2009a) and Liu et al (2014) found the Si addition increased the DMA concentration in rice grain and reproductive tissues of rice whilst Fleck et al (2013) reported that Si application did not affect the DMA content in polished rice. Zhao et al (2013a) demonstrated that As speciation in grain was primarily due to environmental variation, whilst the presence of methylated As species in grain was dependent on soil microbial activities and communities as well as soil type (Zhao et al., 2013b). 


\section{Conclusion}

Greenhouse experiments were conducted to investigate the effects of $\mathrm{Si}$ application on plant growth, As fractionation in soil, and As accumulation and speciation in four rice genotypes (hybrid genotypes XFY-9 and TY-207, and indica subspecies XWX-17 and XWX-12) possessing different radial oxygen loss rates. There were significant differences in root $(\mathrm{P}<0.05)$, straw $(\mathrm{P}<0.001)$ and grain $(\mathrm{P}<0.001)$ biomass between genotypes, and Si application significantly increased root $(\mathrm{P}<0.05)$ and grain biomass $(\mathrm{P}<0.001)$. The sequential extraction procedure demonstrated that there were no significant genotypic differences between As fractions. However, Si addition reduced the proportion of As associated with well-crystallized hydrous oxides of $\mathrm{Fe}$ and $\mathrm{Al}$ and residual phases, whilst increasing the proportion of specifically-sorbed As and As associated with amorphous and poorly- crystalline hydrous oxides of Fe and Al. Additionally, the results indicated that the proportion of As associated with well-crystallized hydrous oxides of Fe and $\mathrm{Al}$ and residual phases in non-rhizosphere soils were much greater than rhizosphere soils with the same treatment. Significant genotypic differences were observed for total As in roots $(\mathrm{P}<0.05)$, husks $(\mathrm{P}<0.01)$ and polished grains $(\mathrm{P}<0.001)$. Silicon application had a significant effect by reducing total As concentrations in root $(\mathrm{P}<0.005)$, straw $(\mathrm{P}<0.05)$ and husk $(\mathrm{P}<0.001)$ of rice plants. SXRF revealed the effects of $\mathrm{Si}$ on decreasing $\mathrm{As}$ accumulation in rice leaves. Indica genotypes transported and accumulated less As and iAs than hybrid genotypes. DMA may have greater translocation capacity from straw to grain than iAs. Silicon reduced iAs and DMA by $21 \%$ and $58 \%$ in rice grains respectively. The study has the potential for further enhancing the understanding of As uptake mechanisms in rice and mitigating the health risks posed by As contamination in paddy fields. 


\section{Acknowledgment}

Financial support from National Natural Science Foundation of China (No. 41201493; 31300815) and Natural Science Foundation of Hunan, China (No. 2015JJ3142) is gratefully acknowledged. Chuan $\mathrm{Wu}$ acknowledged the Postdoctoral Science Foundation of Central South University in Changsha, P.R. China. Thanks are also due to Yang Fei, and Zhaocai Li in Central South University for assisting with various experiments.

\section{Reference}

Abedin, M.J., Feldmann, J., Meharg, A.A., 2002. Uptake kinetics of arsenic species in rice plants. Plant Physiol. 128, 1120-1128.

Bogdan, K., Schenk, M.K., 2008. Arsenic in rice (Oryza sativa L.) related to dynamics of arsenic and silicic acid in paddy soils. Environ. Sci. Technol. 42(21), 7885-7890.

Carey, A.M., Norton, G.J., Deacon, C., Scheckel, K.G., Lomb, E., Punshon, T., Guerinot, M.L, Lanzirotti, A., Newville, M., Choi, Y., Price, A.H., Meharg, A.A., 2011. Phloem transport of arsenic species from flag leaf to grain during grain filling. New. Phytol. 192, 87-98

Chen, X.W., Li, H., Chan, W.F., Wu, C., Wu, F.Y., Wu, S.C., Wong, M.H., 2012. Arsenite transporters expression in rice (Oryza sativa L.) associated with arbuscular mycorrhizal fungi (AMF) colonization under different levels of arsenite stress. Chemosphere 89, 1248-1254.

Colmer, T.D., 2003. Long-distance transport of gases in plants: a perspective on internal aeration and radial oxygen loss from roots. Plant. Cell. Environ. 26 (1), 
$17-36$.

Fendorf, S., Michael, H.A., Geen, A.V., 2010. Spatial and temporal variations of groundwater arsenic in South and Southeast Asia. Science 328, 1123-1127.

Fleck, A.T., Mattusch, J., Schenk, M.K., 2013. Silicon decreases the arsenic level in rice grain by limiting arsenite transport. J. Plant. Nutr. Soil. Sci. 176, $785-794$.

Frost, R.R., Griffin, R.A., 1977. Effect of $\mathrm{pH}$ on adsorption of arsenic and selenium from landfill leachate by clay minerals. Soil. Sci. Soc. Am. J. 41(1), 53-57.

Guo, Z.H., Meghari, M., Beer, M., Ming, H., Rahman, M.M., Wu, W., Naidu, R., 2009. Heavy metal impact on bacterial biomass based on DNA analysis and uptake by wild plants in the abandoned copper mine soils. Bioresource Technol. 100, 3831-3836.

Guo, W., Hou, Y.L., Wang, S.G., Zhu, Y.G., 2005. Effect of silicate on the growth and arsenate uptake by rice (Oryza sativa L.) seedlings in solution culture. Plant Soil 272, 173-181.

Guo, W., Zhu, Y.G., Liu, W.J., Liang, Y.C., Geng, C.N., Wang, S.G., 2007. Is the effect of silicon on rice uptake of arsenate (AsV) related to internal silicon concentrations, iron plaque and phosphate nutrition? Environ. Pollut. 148, 251-257.

Huang, G.X., Chen, Z.Y., Sun, J.C., Liu, F., Wang, J., Zhang, Y., 2015. Effect of sample pretreatment on the fractionation of arsenic in anoxic soils. Environ. Sci. Pollut. R. 22, 8367-8374.

Huang, R.Q., Gao, S.F., Wang, W.L., Staunton, S., Guo, W., 2006. Soil arsenic availability and the transfer of soil arsenic to crops in suburban areas in Fujian Province, southeast China. Sci. Total Environ. 368, 531-541.

Jia, Y., Huang, H., Chen, Z., Zhu, Y.G., 2014. Arsenic uptake by rice is 
influenced by Microbe-Mediated arsenic redox changes in the rhizosphere. Environ. Sci. Technol. 48, 1001-1007.

Jia, Y., Huang, H., Sun, G.X., Zhao, F.J., Zhu, Y.G., 2012. Pathways and relative contributions to arsenic volatilization from rice plants and paddy soil. Environ. Sci. Technol. 46, 8090-8096.

Lee, C.H., Huang, H.H., Syu, C.H., Lin, T.H., Lee, D.Y, 2014. Increase of As release and phytotoxicity to rice seedlings in As-contaminated paddy soils by $\mathrm{Si}$ fertilizer application. J. Hazard. Mater. 276, 253-261.

Li, J.X., Yang, X.E., He, Z.L., Jilani, G., Sun, C.Y., Chen, S.M., 2007. Fractionation of lead in paddy soils and its bioavailability to rice plants. Geoderma 141, 174-180.

Li, R.Y., Ago, Y., Liu, W.J., Mitani, N., Feldmann, J., McGrath, S.P., Ma, J.F., Zhao, F.J., 2009b. The rice aquaporin Lsi1 mediates uptake of methylated arsenic species. Plant Physiol. 150, 2071-2080.

Li, R.Y., Stroud, J.L., Ma, J.F., McGrath, S.P., Zhao, F.J., 2009a. Mitigation of arsenic accumulation in rice with water management and silicon fertilization. Environ. Sci. Technol. 43, 3778-3783.

Liao, X., Chen, T., Xie, H., Liu, Y., 2005. Soil As contamination and its risk assessment in areas near the industrial districts of Chenzhou City, Southern China. Environ. Int. 31, 791-798.

Liu, W.J., McGrath, S.P., Zhao, F.J., 2014. Silicon has opposite effects on the accumulation of inorganic and methylated arsenic species in rice. Plant Soil 376, 423-431.

Luxton, T.P., Eick, M.J., Rimstidt, D.J., 2008. The role of silicate in the adsorption/desorption of arsenite on goethite. Chem. Geol. 252(3), 125-135. 
Ma, J.F., Tamai, K., Yamaji, N., Mitani, N., Konishi, S., Katsuhara, M., Ishiguro, M., Murata, Y., Yano, M., 2006. A silicon transporter in rice. Nature. 440, 688-691.

Ma, J.F., Yamaji, N., Mitani, N., Tamai, K., Konishi, S., Fujiwara, T., Katsuhara, M., Yano, M., 2007. An efflux transporter of silicon in rice. Nature. 448, 209-212.

Ma, J.F., Yamaji, N., Mitani, N., Xu, X.Y., Su, Y.H., McGrath, S.P., Zhao, F.J., 2008. Transporters of arsenite in rice and their role in arsenic accumulation in rice grain. Proc. Natl. Acad. Sci. USA 105 (29), 9931-9935.

Martinez, V.D., Vucic, E.A., Becker-Santos, D.D., Gil, L., and Lam, W.L., 2011. Arsenic exposure and the induction of human cancers. Journal of Toxicology, 431287.

Martinez-Sanchez, M.J., Martinez-Lopez, S., Garcia-Lorenzo, M.L., Martinez-Martinez, L.B., Perez-Sirvent, C., 2011. Evaluation of arsenic in soils and plant uptake using various chemical extraction methods in soils affected by old mining activities. Geoderma. 160, 535-541.

Meharg, A.A., Williams, P.N., Adomako, E., Lawgali, Y.Y., Deacon, C., Villada, A., Cambell, R.C.J., Sun, G.X., Zhu, Y.G., Feldmann, J., Raab, A., Zhao, F.J., Islam, R., Hossain, S., Yanai, J., 2009. Geographical variation in total and inorganic arsenic content of polished (White) rice. Environ. Sci. Technol. 43, 1612-1617.

Meharg, A.A.; Zhao, F.J., Risk from arsenic in rice grain. In Arsenic \& Rice; Springer: London, New York, 2012; pp 31-50.

Mei, X.Q., Wong, M.H., Yang, Y., Dong, H.Y., Qiu, R.L., Ye, Z.H., 2012. The effects of radial oxygen loss on arsenic tolerance and uptake in rice and on its rhizosphere. Environ. Pollut. 165, 109-117.

Mei, X.Q., Ye, Z.H., Wong, M.H., 2009. The relationship of root porosity and radial oxygen loss on arsenic tolerance and uptake in rice grains and straw. Environ. Pollut. 157, 2550-2557. 
Novoa-Munoz, J.C., Queijeiro, J.M.G., Blanco-Ward, D., Alvarez-Olleros, C., Garcia-Rodeja, E., Martinez-Cortizas, A., 2007. Arsenic fractionation in agricultural acid soils from NW Spain using a sequential extraction procedure. Sci. Total Environ. $378,18-22$.

Nriagu, J.O., Bhattacharya, P., Mukherjee, A.B., Bundschuh, J., Zevenhoven, R., Loeppert, R.H., 2007. Arsenic in soil and groundwater: An overview. Trace Metals \& Other Contaminants in the Environment 9, 3-60.

Pan, W.S., Wu, C., Xue, S.G., Hartley, W., 2014. Arsenic dynamics in the rhizosphere and its sequestration on rice roots as affected by root oxidation. J. Environ. Sci. 26, 892-899.

Peng, B., Song, T.T, , Wang, T., Chai, L.Y., Yang, W.C, Li, X.R., Li, C.F., Wang, H.Y. 2016. Facile synthesis of $\mathrm{Fe}_{3} \mathrm{O}_{4} @ \mathrm{Cu}(\mathrm{OH})_{2}$ composites and their arsenic adsorption application. Chem. Eng. J. 299, 15-22.

Roberts, L.C., Hug, S.J., Andreas, V., Jessica, D., Ruben, K., Bernhard, W., Saha, G.C., Badruzzaman, A.B.M., M Ashraf, A., 2011. Arsenic Dynamics in Porewater of an Intermittently Irrigated Paddy Field in Bangladesh. Environ. Sci. Technol. 45, 971-976.

Sanchez, G.A., Alvarez, A.E., 2003. Arsenic in soils and waters and its relation to geology and mining activities (salamanca province, spain). J. Geochem. Explor. 80(1), 69-79.

Seyfferth, A.L., Fendorf, S., 2012. Silicate Mineral Impacts on the Uptake and Storage of Arsenic and Plant Nutrients in Rice (Oryza sativa L.). Environ. Sci. Technol. 46, 13176-13183.

Shi, G.L., Lou, L.Q., Zhuang, S., Xia, X.W., Cai, Q.S., 2013. Arsenic, copper 
and zinc contamination in soil and wheat during coal mining with assessment of health risks for the inhabitants of Huaibei, China. Environ. Sci. Pollut. Res. 20 (12), $8435-8445$.

Smith, E., Juhasz, A.L., Weber, J., Naidu, R., 2008. Arsenic uptake and speciation in rice plants grown under greenhouse conditions with arsenic contaminated irrigation water. Sci. Total Environ. 392, 277-283.

Stone, R., 2008. Arsenic and paddy rice: a neglected cancer risk. Nature 321, $184-185$.

Stroud, J.L., M Asaduzzman, K., Norton, G.J., M Rafiqul, I., Tapash, D., Yong-Guan, Z., Price, A.H., Meharg, A.A., Mcgrath, S.P., Fang-Jie, Z., 2011. Assessing the labile arsenic pool in contaminated paddy soils by isotopic dilution techniques and simple extractions. Environ. Sci. Technol. 45, 4262-4269.

Su, Y.H., Mcgrath, S.P., Zhao, F.J., 2009. Rice is more efficient in arsenite uptake and translocation than wheat and barley. Plant \& Soil 328, 27-34.

Syu, C.H., Huang, C.C., Jiang, P.Y., Lee, C.H., Lee, D.Y., 2015.Arsenic accumulation and speciation in rice grains influenced by arsenic phytotoxicity and rice genotypes grown in arsenic-elevated paddy soils. J. Hazard Mater. 286, 179-186

Takahashi, Y., Minamikawa, R., Hattori, K.H., Kurishima, K., Kihou, N., Yuita, K., 2004. Arsenic behavior in paddy fields during the cycle of flooded and non-flooded periods. Environ. Sci. Technol. 38, 1038-1044.

Tang, X.Y., Zhu, Y.G., Shan, X,Q., McLaren, R., Duan, J., 2007. The ageing effect on the bioaccessibility and fractionation of arsenic in soils from China. Chemophere 66, 1183-1190.

Tripathi, P., Tripathi, R.D., Singh, R.P., Dwivedi, S., Goutam, D., Shri, M., Trivedi, P.K., Chakrabarty, D., 2013. Silicon mediates arsenic tolerance in rice (Oryza 
sativa L.) through lowering of arsenic uptake and improved antioxidant defence system. Ecol. Eng. 52, 96-103.

Wang, T., Zhang, L.Y, Wang, H.Y., Li, C.F., Yang, W.C., Chai, L.Y., Dai, S., Meng, Y., 2015. Synthesis of core shell magnetic $\mathrm{Fe}_{3} \mathrm{O}_{4} @$ poly(m-phenylenediamine) particles with high chromium removal performance. Environ. Sci. Technol., 49, $5654-5662$.

Wenzel, W.W., Kirchbaumer, N., Prohaska, T., Stingeder, G., Lombi, E., Adriano, D.C., 2001. Arsenic fractionation in soils using an improved sequential extraction procedure. Anal. Chim. Acta. 436, 309-323.

Wu, C., Ye, Z.H., Shu, W.S., Zhu, Y.G., Wong, M.H., 2011. Arsenic accumulation and speciation in rice are affected by root aeration and variation of genotypes. J. Exp. Bot. 62, 2889-2898.

Wu, C., Zou, Q., Xue, S.G., Mo, J.Y., Pan, W.S., Lou, L.Q., Wong, M.H., 2015. Effects of silicon $(\mathrm{Si})$ on arsenic (as) accumulation and speciation in rice (Oryza sativa L.) genotypes with different radial oxygen loss (ROL). Chemosphere 138, 447-453.

Wu, C., ZOU, Q., Xue, S.G., Pan, W.S., Huang, L., Hartley W., Mo, J.Y., Wong, M.H., 2016. The effect of silicon on iron plaque formation and arsenic accumulation in rice genotypes with different radial oxygen loss (ROL), Environ. Pollut. 212, $27-33$

Xu, X.Y., McGrath, S.P., Meharg, A.A., Zhao, F.J., 2008. Growing rice aerobically markedly decreases arsenic accumulation. Environ. Sci. Technol. 42, $5574-557$.

Xue, S.G., Zhu, F., Kong, X.F., Wu, C., Huang, L., Huang, N., Hartley, W., 2016. A review of the characterization and revegetation of bauxite residues (Red mud). 
Environ. Sci. Pollut. Res. 23, 1120-1132.

Yamaguchi, N., Ohkura, T., Takahashi, Y., Maejima, Y., Arao, T., 2014. Arsenic distribution and speciation near rice roots influenced by iron plaques and redox conditions of the soil matrix. Environ. Sci. Technol. 48, 1549-1556.

Yang, F., Zhao, L., Gao, B., Xu, X.Y., Cao, X.D., 2016. The interfacial behavior between biochar and soil minerals and its effect on biochar stability. Environ. Sci. Technol. 50, 2264-2271.

Zavala, Y.J., Duxbury, J.M., 2008. Arsenic in rice: I. Estimating normal levels of total arsenic in rice grain. Environ. Sci. Technol. 42, 3856-3860

Zhao, F.J., Zhu, Y.G, Meharg, A.A., 2013a. Methylated arsenic species in rice: Geographical variation, origin, and uptake mechanisms. Environ. Sci. Technol. 47, 3957-3966.

Zhao, F.J., Harris, E., Yan, J., Ma, J.C., Wu, L.Y., Liu, W.J., McGrath, S.P., Zhou, J.Z., Zhu, Y.G., 2013b. Arsenic methylation in soils and its relationship with microbial arsM abundance and diversity, and As speciation in rice. Environ. Sci. Technol. 47, 7147-7154.

Zheng, M.Z., Cai, C., Hu, Y., Sun, G.X., Williams, P.N., Cui, H.J., Li, G., Zhao, F.J, Zhu, Y.G., 2011. Spatial distribution of arsenic and temporal variation of its concentration in rice. New Phytol. 189, 200-209.

Zheng, M.Z., Li, G., Sun, G.X., Shim, H., Cai, C., 2013. Differential toxicity and accumulation of inorganic and methylated arsenic in rice. Plant Soil 365, 227-238.

Zhu, F., Liao J.X., Xue, S.G., Hartley, W., Zou Q., Wu, Hao., 2016. Evaluation of aggregate microstructures following natural regeneration in bauxite residue as characterized by synchrotron-based X-ray micro-computed tomography. Sci. Total 
Environ. 573, 155-163.

Zhu, Y.G., Williams, P.N., Meharg, A.A., 2008. Exposure to inorganic arsenic from rice: A global health issue? Environ. Pollut. 154, 169-171.

Zhu, Y.G., Sun, G.X., Lei, M., Teng, M., Liu, Y.X., Chen, N.C., Wang, L.H., Carey, A.M., Deacon, C., Raab, A., Meharg, A.A., Williams, P.N., 2008. High percentage inorganic arsenic content of mining impacted and nonimpacted Chinese rice. Environ. Sci. Technol. 42, 5008-5013. 
Table 1 Total As concentrations of four rice genotypes subjected to different treatments

\begin{tabular}{|c|c|c|c|c|c|}
\hline Genotypes & Treatments & Root & Straw & Husk & Grain \\
\hline \multirow[t]{4}{*}{ XFY-9 } & $\mathrm{Si}-0$ & $900 \pm 52.2$ & $11.3 \pm 1.49$ & $5.84 \pm 2.40$ & $2.73 \pm 0.22$ \\
\hline & Si-10 & $783 \pm 144$ & $10.3 \pm 1.10$ & $4.35 \pm 1.17$ & $1.68 \pm 0.63$ \\
\hline & $\mathrm{Si}-20$ & $799 \pm 192$ & $9.91 \pm 2.10$ & $3.06 \pm 1.14$ & $1.80 \pm 0.07$ \\
\hline & $\mathrm{Si}-40$ & $631 \pm 46.7$ & $9.66 \pm 1.56$ & $3.32 \pm 1.87$ & $1.65 \pm 0.52$ \\
\hline \multirow[t]{4}{*}{ TY-207 } & $\mathrm{Si}-0$ & $753 \pm 234$ & $11.6 \pm 2.00$ & $5.27 \pm 2.16$ & $2.42 \pm 0.05$ \\
\hline & $\mathrm{Si}-10$ & $661 \pm 31.9$ & $9.05 \pm 1.79$ & $3.56 \pm 1.50$ & $2.26 \pm 1.32$ \\
\hline & $\mathrm{Si}-20$ & $535 \pm 126$ & $8.48 \pm 2.40$ & $4.79 \pm 1.13$ & $2.34 \pm 0.75$ \\
\hline & $\mathrm{Si}-40$ & $488 \pm 144$ & $9.99 \pm 2.33$ & $5.45 \pm 0.40$ & $1.45 \pm 0.24$ \\
\hline \multirow[t]{4}{*}{ XWX-17 } & $\mathrm{Si}-0$ & $692 \pm 145$ & $11.1 \pm 3.62$ & $6.79 \pm 1.57$ & $1.70 \pm 0.12$ \\
\hline & $\mathrm{Si}-10$ & $834 \pm 113$ & $9.85 \pm 1.48$ & $3.22 \pm 0.75$ & $1.39 \pm 0.71$ \\
\hline & $\mathrm{Si}-20$ & $709 \pm 144$ & $8.62 \pm 1.42$ & $3.51 \pm 0.93$ & $2.03 \pm 0.43$ \\
\hline & $\mathrm{Si}-40$ & $583 \pm 154$ & $7.24 \pm 0.98$ & $2.95 \pm 1.58$ & $1.41 \pm 0.59$ \\
\hline \multirow[t]{4}{*}{ XWX-12 } & $\mathrm{Si}-0$ & $946 \pm 135$ & $12.8 \pm 1.94$ & $4.19 \pm 1.10$ & $1.63 \pm 0.08$ \\
\hline & $\mathrm{Si}-10$ & $816 \pm 273$ & $8.39 \pm 1.25$ & $2.78 \pm 0.95$ & $1.04 \pm 0.13$ \\
\hline & $\mathrm{Si}-20$ & $772 \pm 104$ & $9.07 \pm 1.84$ & $2.02 \pm 0.69$ & $1.21 \pm 0.35$ \\
\hline & $\mathrm{Si}-40$ & $677 \pm 141$ & $11.8 \pm 3.82$ & $1.89 \pm 0.26$ & $0.94 \pm 0.47$ \\
\hline \multicolumn{6}{|c|}{ Analysis of variance } \\
\hline \multicolumn{2}{|c|}{ Genotype(G) } & $\mathrm{P}<0.05$ & NS & $\mathrm{P}<0.01$ & $\mathrm{P}<0.001$ \\
\hline \multicolumn{2}{|l|}{$\mathrm{Si}$} & $\mathrm{P}<0.005$ & $\mathrm{P}<0.05$ & $\mathrm{P}<0.001$ & NS \\
\hline \multicolumn{2}{|l|}{$\mathrm{G} \times \mathrm{Si}$} & NS* & NS & NS & NS \\
\hline
\end{tabular}


Table 2 Proportions of As species in rice straws subjected to different treatments

\begin{tabular}{|c|c|c|c|c|c|c|c|}
\hline \multirow[b]{2}{*}{ Genotype } & \multirow[b]{2}{*}{ Treatment } & Total As & iAs & DMA & MMA & \multirow[b]{2}{*}{ iAS $(\%)$} & \multirow{2}{*}{$\begin{array}{c}\text { Recovery } \\
(\%)\end{array}$} \\
\hline & & & & & & & \\
\hline \multirow[t]{3}{*}{ XFY-9 } & $\mathrm{Si}-0$ & $11.3 \pm 1.49$ & $13.6 \pm 3.99$ & $1.04 \pm 0.15$ & $0.25 \pm 0.02$ & 91 & 132 \\
\hline & $\mathrm{Si}-20$ & $9.91 \pm 2.10$ & $8.50 \pm 3.05$ & $2.01 \pm 0.35$ & $0.37 \pm 0.17$ & 78 & 110 \\
\hline & $\mathrm{Si}-40$ & $9.66 \pm 1.56$ & $5.46 \pm 2.13$ & $0.89 \pm 0.48$ & $0.04 \pm 0.02$ & 85 & 66 \\
\hline \multirow{3}{*}{ XWX-12 } & $\mathrm{Si}-10$ & $8.39 \pm 1.25$ & $8.96 \pm 2.52$ & $1.85 \pm 0.29$ & $0.28 \pm 0.09$ & 81 & 132 \\
\hline & $\mathrm{Si}-20$ & $9.08 \pm 1.84$ & $8.82 \pm 1.71$ & $1.35 \pm 0.51$ & $0.17 \pm 0.04$ & 85 & 114 \\
\hline & $\mathrm{Si}-40$ & $11.8 \pm 3.82$ & $9.20 \pm 2.76$ & $1.14 \pm 0.26$ & $0.13 \pm 0.06$ & 78 & 96 \\
\hline
\end{tabular}


Table 3 Proportions of As species in rice husks subjected to different treatments

\begin{tabular}{|c|c|c|c|c|c|c|c|}
\hline \multirow[b]{2}{*}{ Genotype } & \multirow[b]{2}{*}{ Treatment } & \multirow{2}{*}{$\begin{array}{l}\text { Total As } \\
(\mathrm{mg} / \mathrm{kg})\end{array}$} & \multirow{2}{*}{$\begin{array}{l}\text { iAs } \\
\text { (mg/kg) }\end{array}$} & \multirow{2}{*}{$\begin{array}{r}\text { DMA } \\
(\mathrm{mg} / \mathrm{kg})\end{array}$} & \multirow{2}{*}{$\begin{array}{l}\text { MMA } \\
(\mathrm{mg} / \mathrm{kg})\end{array}$} & \multirow{2}{*}{$\begin{array}{l}\text { iAs } \\
(\%)\end{array}$} & \multirow{2}{*}{$\begin{array}{r}\text { Recovery } \\
(\%)\end{array}$} \\
\hline & & & & & & & \\
\hline \multirow[t]{4}{*}{ XFY-9 } & $\mathrm{Si}-0$ & $5.84 \pm 2.40$ & $1.41 \pm 0.056$ & $1.86 \pm 0.19$ & $0.047 \pm 0.009$ & 43 & 57 \\
\hline & Si-10 & $4.35 \pm 1.17$ & $0.958 \pm 0.133$ & $1.61 \pm 0.25$ & $0.033 \pm 0.003$ & 37 & 60 \\
\hline & $\mathrm{Si}-20$ & $3.06 \pm 1.14$ & $0.635 \pm 0.058$ & $1.59 \pm 0.11$ & $0.045 \pm 0.015$ & 28 & 74 \\
\hline & Si-40 & $3.32 \pm 1.87$ & $0.632 \pm 0.265$ & $1.36 \pm 0.53$ & $0.031 \pm 0.020$ & 31 & 61 \\
\hline \multirow[t]{4}{*}{ XWX-12 } & $\mathrm{Si}-0$ & $4.19 \pm 1.10$ & $1.20 \pm 0.070$ & $3.07 \pm 0.65$ & $0.073 \pm 0.008$ & 28 & 104 \\
\hline & $\mathrm{Si}-10$ & $2.78 \pm 0.95$ & $0.716 \pm 0.149$ & $2.45 \pm 0.32$ & $0.038 \pm 0.011$ & 22 & 115 \\
\hline & Si-20 & $2.02 \pm 0.69$ & $0.633 \pm 0.030$ & $2.19 \pm 0.71$ & $0.031 \pm 0.015$ & 22 & 141 \\
\hline & Si-40 & $1.89 \pm 0.26$ & $0.538 \pm 0.068$ & $1.72 \pm 0.75$ & $0.025 \pm 0.023$ & 24 & 121 \\
\hline
\end{tabular}


Table 4 Proportions of As species in rice grains subjected to different treatments

\begin{tabular}{|c|c|c|c|c|c|c|c|}
\hline \multirow[b]{2}{*}{ Genotype } & \multirow[b]{2}{*}{ Treatment } & Total As & iAs & DMA & MMA & iAs & \multirow{2}{*}{$\begin{array}{c}\text { Recovery } \\
(\%)\end{array}$} \\
\hline & & $(\mathrm{mg} / \mathrm{kg})$ & $(\mathrm{mg} / \mathrm{kg})$ & $(\mathrm{mg} / \mathrm{kg})$ & $(\mathrm{mg} / \mathrm{kg})$ & $(\%)$ & \\
\hline \multirow[t]{4}{*}{ XFY-9 } & $\mathrm{Si}-0$ & $2.73 \pm 0.22$ & $0.235 \pm 0.023$ & $2.4 \pm 0.28$ & ND* & 8.9 & 97 \\
\hline & Si-10 & $1.68 \pm 0.63$ & $0.207 \pm 0.026$ & $2.08 \pm 0.62$ & ND & 9.1 & 136 \\
\hline & $\mathrm{Si}-20$ & $1.80 \pm 0.07$ & $0.211 \pm 0.023$ & $2.12 \pm 0.23$ & ND & 9.1 & 130 \\
\hline & Si-40 & $1.65 \pm 0.52$ & $0.198 \pm 0.026$ & $2.04 \pm 0.74$ & ND & 8.9 & 136 \\
\hline \multirow[t]{4}{*}{ XWX-12 } & $\mathrm{Si}-0$ & $1.63 \pm 0.08$ & $0.094 \pm 0.015$ & $1.93 \pm 0.77$ & ND & 4.6 & 124 \\
\hline & $\mathrm{Si}-10$ & $1.04 \pm 0.13$ & $0.074 \pm 0.012$ & $1.27 \pm 0.15$ & ND & 5.5 & 129 \\
\hline & $\mathrm{Si}-20$ & $1.21 \pm 0.35$ & $0.107 \pm 0.016$ & $1.29 \pm 0.34$ & ND & 7.7 & 115 \\
\hline & Si-40 & $0.94 \pm 0.47$ & $0.076 \pm 0.011$ & $0.82 \pm 0.25$ & ND & 8.5 & 95 \\
\hline
\end{tabular}

*Not detectable 


\section{Figure captions}

Fig. 1. Biomass of roots, straws and grains in rice plants of four genotypes in different treatments $(\mathrm{mg} / \mathrm{kg}$, mean $\pm \mathrm{SD})$

Fig. 2. Arsenic fractionation in rhizosphere and non-rhizosphere soils in different treatments and different genotypes (a, XFY-9; b, Y-207; c, XWX-17; d, XWX-12).

Fig. 3. The relationship between As concentration in straw and grain in rice plants of four genotypes in different Si treatments.

Fig. 4. Synchrotron X-ray fluorescence (SXRF) images of As distribution in the leaves of rice (Oryza sativa) plants of XFY-12 genotypes in control treatments (a) and Si20 treatments (b). The emission intensity of each pixel was normalized using the beam intensity as a reference. The figure shows a leaf section (left) and As signals in SXRF images (right). Note that high As signals coincided with the veins shown in the leaf section.

Fig. 5. The relationship between iAs (a) and DMA (b) concentrations in rice straw with the concentrations in rice grains of two genotypes. 

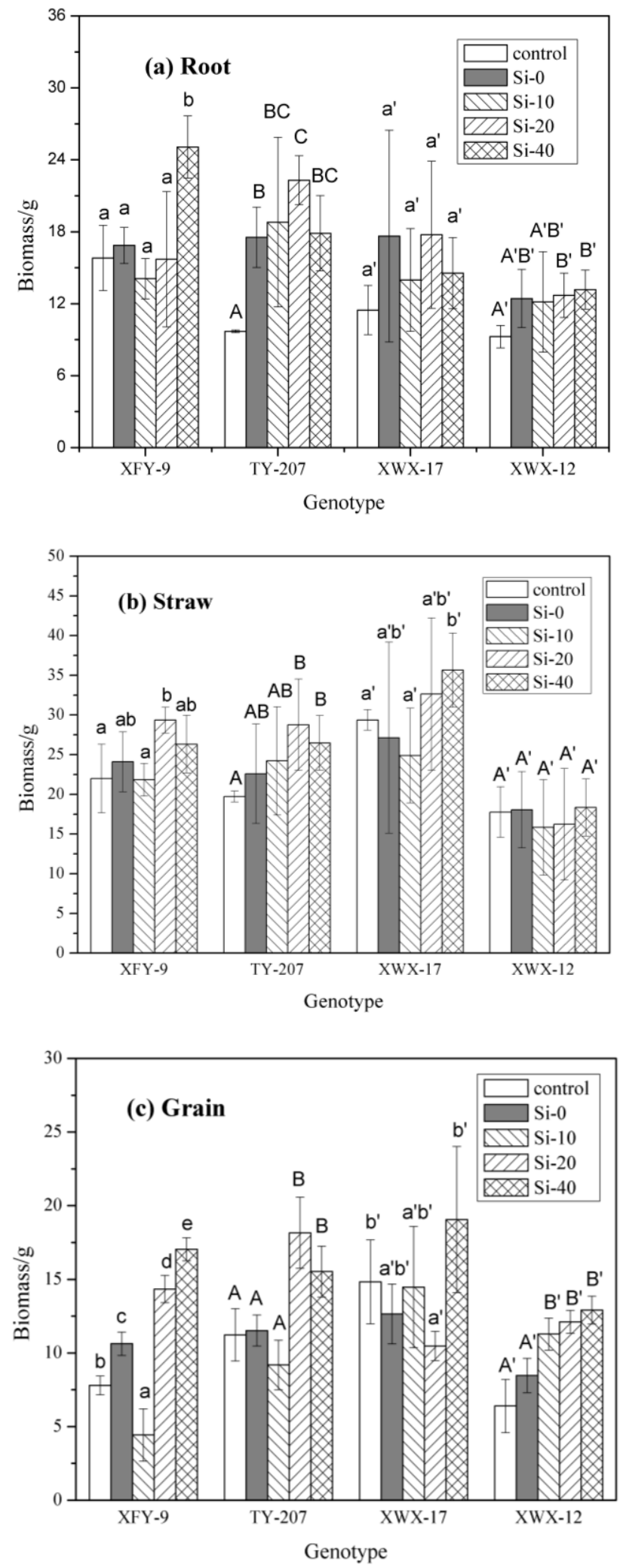

Fig. 1. Biomass of roots, straws and grains in rice plants of four genotypes in different treatments $(\mathrm{mg} / \mathrm{kg}$, mean $\pm \mathrm{SD})$ 

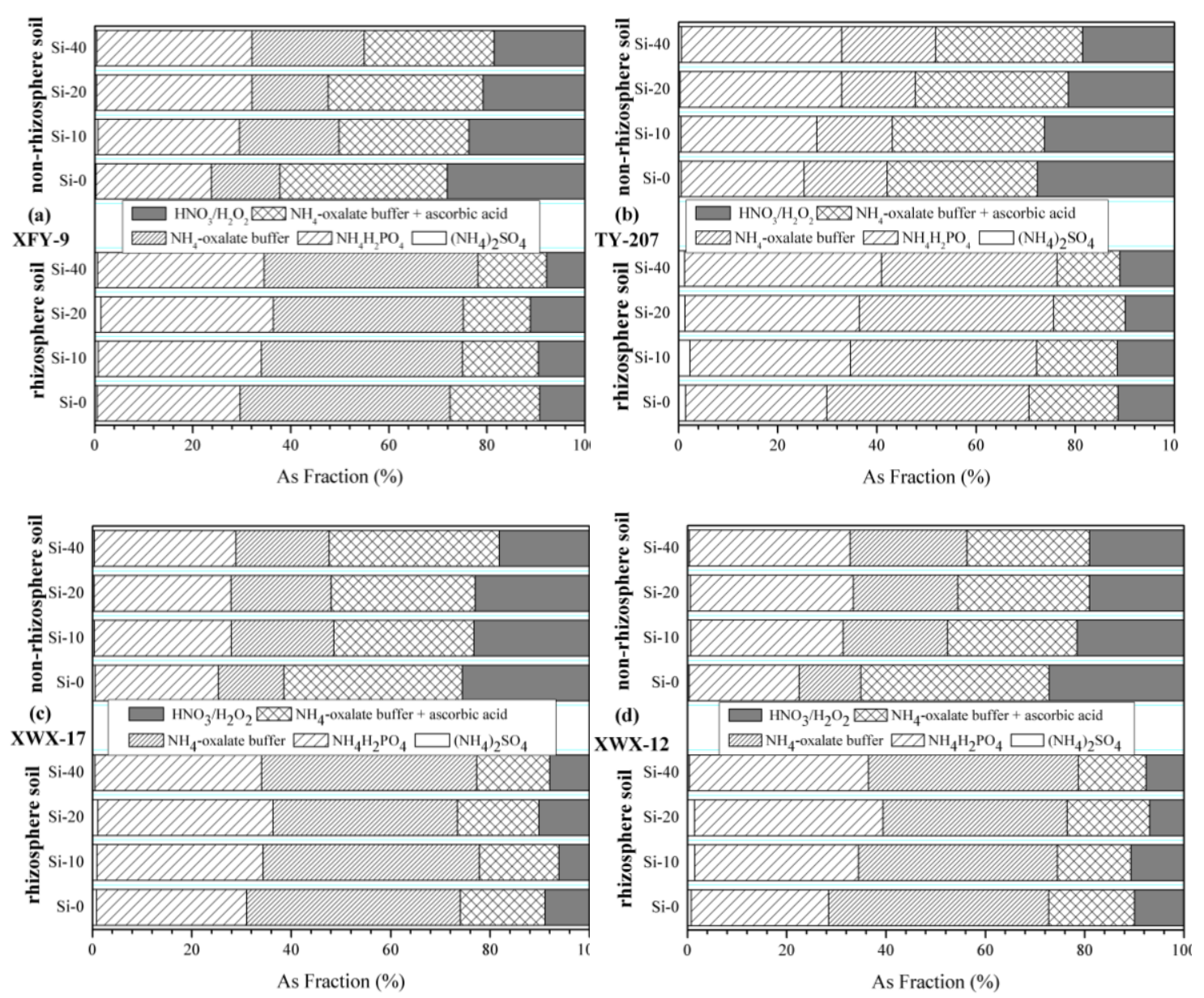

Fig. 2. Arsenic fractionation in rhizosphere and non-rhizosphere soils in different treatments and different genotypes (a, XFY-9; b, Y-207; c, XWX-17; d, XWX-12). 


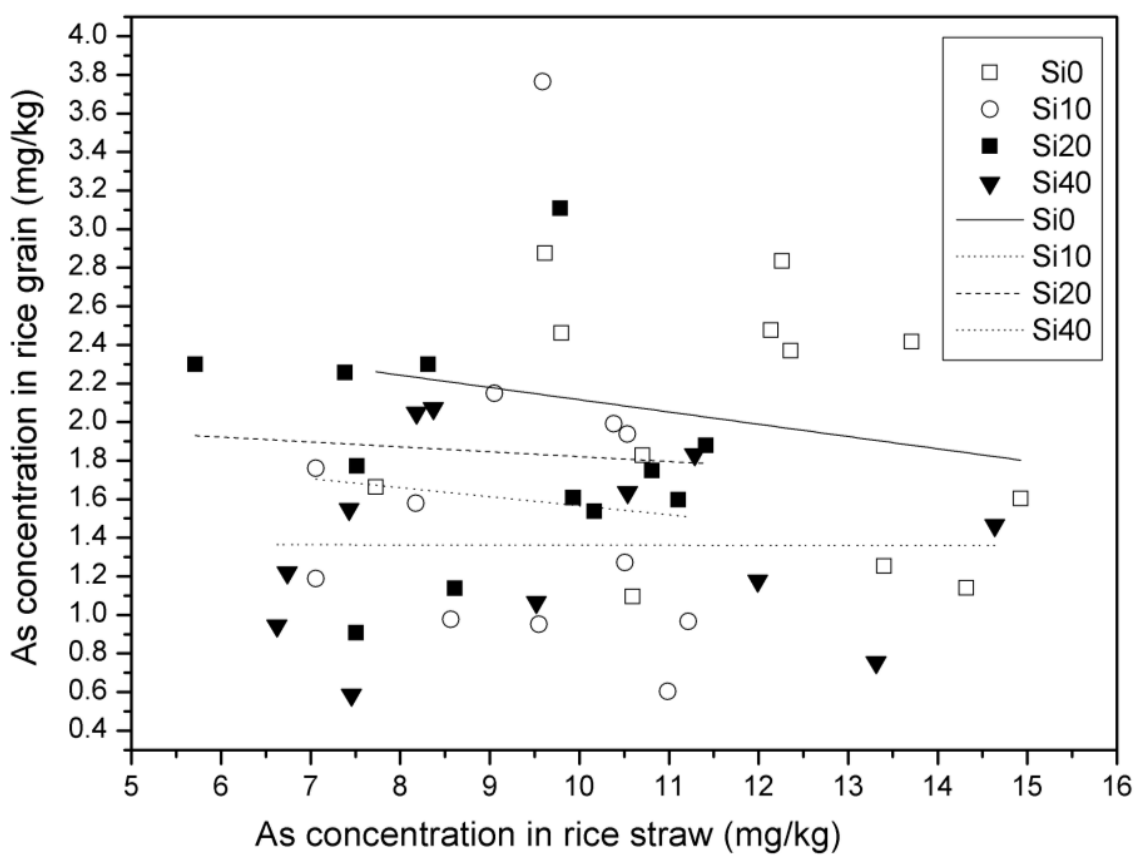

Fig. 3. The relationship between As concentration in straw and grain in rice plants of four genotypes in different Si treatments. 
(a)

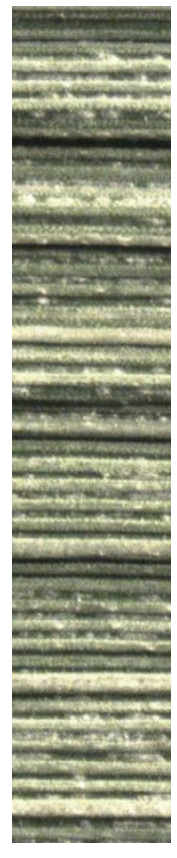

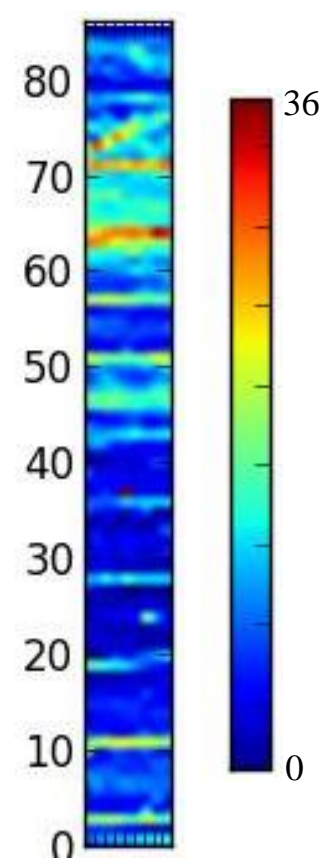

(b)

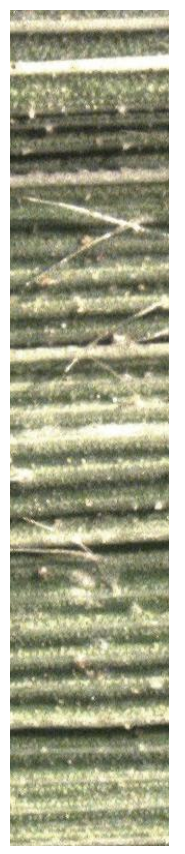

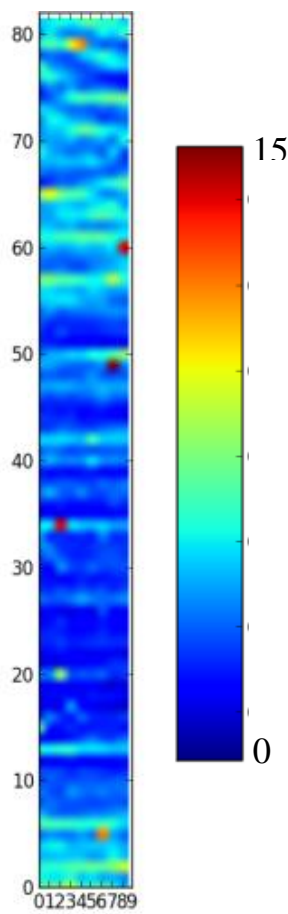

Fig. 4. Synchrotron X-ray fluorescence (SXRF) images of As distribution in the leaves of rice (Oryza sativa) plants of XFY-12 genotypes in control treatments (a) and Si20 treatments (b). The emission intensity of each pixel was normalized using the beam intensity as a reference. The figure shows a leaf section (left) and As signals in SXRF images (right). Note that high As signals coincided with the veins shown in the leaf section. 

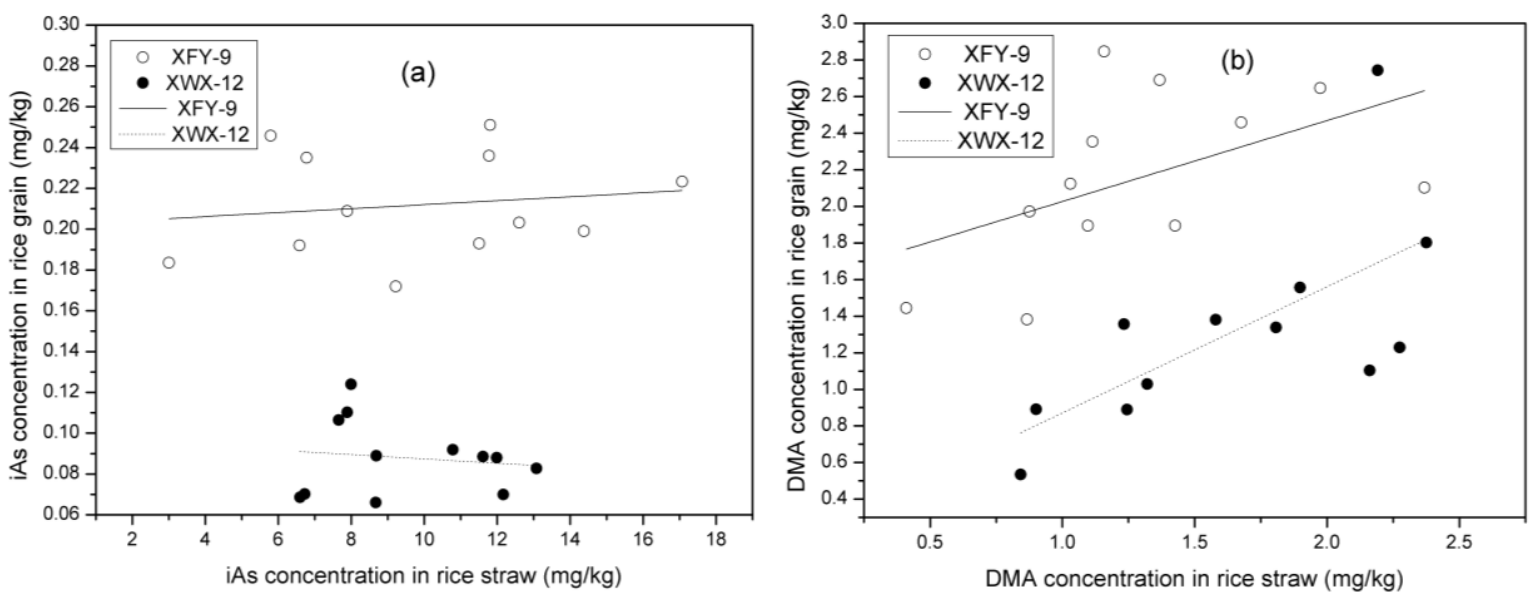

Fig. 5. The relationship between iAs (a) and DMA (b) concentrations in rice straw with the concentrations in rice grains of two genotypes. 